\title{
ENGLISH FOR NURSING STUDENTS BASED ON TASK-BASED LEARNING
}

\author{
*Ahmad Rusli ${ }^{1}$, Jufrizal ${ }^{2}$, Hamzah $^{3}$ \\ ${ }^{123}$ English Education Program, Graduate Program, \\ Universitas Negeri Padang, Indonesia \\ Email: tongkurusli.hrp@gmail.com \\ *Corresponding Author, Received: November 12, 2018, Revised: December 10, 2018, Accepted: December 21, 2018
}

\begin{abstract}
The aim of this research was to develop English learning materials based on task-based learning in the form of handout for nursing study program students at STIKES Aufa Royhan Padang Sidempuan. In the development process, this research used to: 1) identify the needs of teaching/learning Englishof the students; 2) develop English learning materials based on task-based learning; 3) find out the experts' judgments about the developed handout; 4) find out the users' perceptions about the developed handout. Research method was Research and Development (R\&D). ADDIE model used to develop the handout. The result of needs analysis indicated the students needed to learn English language use in the nursing context. Then appropriate handout of English for Nursing was developed based on the result of needs analysis. Based on the experts judgments and users' perception, the developed handout are categorized valid, effective, and practical.
\end{abstract}

Keywords: Handout, English for Nursing Students, Task-Based Learning

\section{INTRODUCTION}

Nursing study program was one of program at STKIES Aufa Royhan Padang Sidempuan. The mission of the program was to educate and prepare the students in order to be excellent and competent nurse professional in regional, national, and international. Consequently, the students should learn English in order they were able to use the English language properly in nursing context beside to fill the mission. Hyland (2006) said that English for nursing was part of English for academic concept in which students took one broader and heterogeneous academic subjects through genre, departments, and disciplines of nursing. In addition, Finch (2014) explained that 


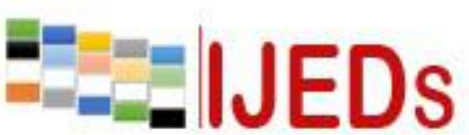

http://ijeds.ppj.unp.ac.id/index.php/IJEDS

English for Nursing was language teaching/learning for medical/nursing purpose that promote a curricula based on humanistic, diagnosis, treatment, and aftercare. Moreover, English for nursing offered communication clearly, sensitively, and effective.

One of effort to reach the previous goal was providing relevant English learning materials that encourage the students' language needs. The needs analysis was taken to provide the students with appropriate English learning materials. Hyland (2006) stated the need analysis used to identify the target and learning needs. In addition, the needs analysis conducted to obtain data/information about the students language needs based on the necessities, lacks, and wants (Evans and John, 2008). For this case, Evans and John (2008) explained that the necessities referred to what the learner had to know in order to function effectively in the target situation. Lacks referred to the discrepancy between necessity and what the learner already knows and it conducted to obtain the data of current or present situation, such as the students background knowledge, level of ability, etc. In the last, wants referred to what the learner actually wants to learn or what they feel they need and it was done to get the information about what the students needs in learning activities to achieve the target situation needs. Furthermore, the information/data from the needs analysis were gained by asking several questions for the students/respondents, such as why the language needed, how the language would be used, what the content areas would be, who the students would use the language with, where the language be used, and when the language would be used (Hutchinson and Waters, 2008).

The existed course syllabus of English for nursing study program at STKIES Aufa Royhan Padang Sidimpuan, the aim of this course was preparing the students in order to be able to apply English as communication tool in daily life as well as the students used terminologies of nursing orally or written. In fact, the students of this course used English learning materials that developed by the lecturer who taught the course. Based on the interview with the lecturer in the preliminary research, the English materials were designed on the course syllabus that she developed. Unfortunately, both course syllabus and the English learning materials were not developed based on a need analysis. Instead, the course syllabus and English learning materials were designed based on her search in the internet without looking the compatibility of the students 


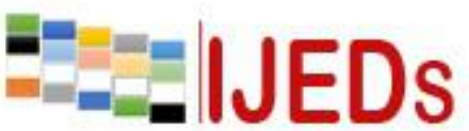

http://ijeds.ppj.unp.ac.id/index.php/IJEDS

needs in teaching/learning English. Then the English learning materials were not designed by using particular pedagogical approach as the basis of the materials development. Consequently, the English learning materials could not cater the students language needs. Moreover, the students found difficulties in applying as well as training the language skills in the study of nursing and future job. Thus, the researcher assumes that the existed English learning materials were not appropriate with the students specific language needs as well as the needs in teaching/learning of English for nursing.

Considering that condition above, the researcher assumed that it was crucial to develop appropriate English learning materials, especially for nursing study program students at STIKES Aufa Royhan Padang Sidempuan. The developing of English course materials was the process to produce the English materials based specific purposes in the using of English. Hyland, (2006) explained that English course materials development needed to produce the authentic materials based on specific purposes. In addition, Hutchinson and Waters (2008) stated there were six considerations that should be filled by the ESP designers in developing the English course materials, namely: a) the materials can stimulates to learning process; b) the materials can organize the teaching and learning process; c) the materials shows the nature of language learning; d) the materials represent learning task; e) the materials useful for specific disciplines; and f) the materials provide certain model.

In this research, the handout was the form of English learning materials that could be developed. According to Mikits (2009), handout was a form of technology that allowed the students to gather, process, and retain information more quickly and easily in the teaching/learning process. The handout could be a very useful tool for the students that enhance the learning process. Therefore, the handout used to fit the need of the class and the expected student effort. In this case, the handout should be authentic, meet the students' learning needs and facilitate the students' understanding. Moreover, the handout as the English learning material should be focused to train as well as develop students communicative competence (Hyland, 2006). Then Hyland (2006) stated that the handout should be compatibility to show the relationship between the materials with contents. Thus, the materials should be well organization designed. 


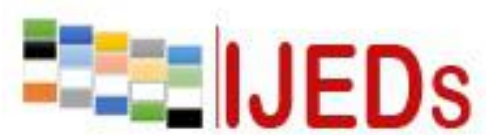

http://ijeds.ppj.unp.ac.id/index.php/IJEDS
International Journal of Educational Dynamics

Vol. 1 No. 1 (pp. 41-54) December 2018

p_ISSN 2655-4852

e_ISSN 2655-5093

The development of the handout involved not only target situation analysis and learning needs analysis, but also an appropriate approach, namely task-based learning. Task-based learning promoted the students' cognitive challenge. For this case, the task-based learning was the highlights instrumental value of language. By having the task-based learning, the students would be engaged by the task to develop strategies and reflective skills. The task was organized with the task sequences in generating language issues as well as students' language needs. Therefore, the TASK was core of teaching/learning through the task-based learning. (Field, 2011; Estaire and Javier, 2003).

According to Ellis (2014) that tasks were categorized to the pedagogical and real-world tasks. Both pedagogical and real-world task should take input as well as production based. Therefore, the using of tasks (pedagogical and real-world tasks) was determined through the students needs in using language in which the needs were generated in the tasks. Ellis (2014) said pedagogic-tasks aimed only at interactional authenticity (i.e. they do not correspond to real life events but still generate natural language use). Thus, pedagogical tasks were mainly offered in the classroom in which the communicative was the goal. In other side, the real-world tasks aimed at both situational and interactional authenticity in that they mirror the actual tasks that learners might have to perform in real life. By having the real-world tasks, the students were able to apply the communicative language of the tasks in the classroom as well as the real life of the students. For this case, the task about nursing context was the one of real-world task. In addition, Windari (2014) stated that the implementation of task-based learning was performing task relevant to the students future profession and it was used to increase the students motivation in teaching/learning of English.

Based on the previous explanation, the task-based learning was chosen because it covered a needs-based approach to content selection. Moreover, the task-based learning offered the authentic texts into the learning situation. The task-based learning entered the students to focus not only on language but also on the learning process itself, and the linking of classroom language learning with language use outside the classroom. For those reasons, the task-based learning was viewed as an appropriate approach for developing English learning materials for nursing study program students at STIKES 


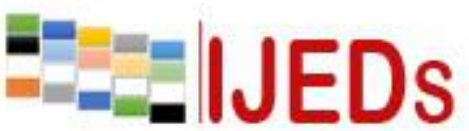

http://ijeds.ppj.unp.ac.id/index.php/IJEDS

Aufa Royhan Padang Sidempuan. For this case, there were some purposes that needed to gain through the developing handout English for nursing, namely: a) to identify the students needs of English learning materials for nursing study program students at STIKES Aufa Royhan Padang Sidempuan; b) to find out the procedures of developing English learning materials based on task-based learning; c) to identify the experts judgments about the developed English learning materials based on task-based learning; d) to find out the users' perception about the developed English learning materials based on task-based learning.

\section{METHOD}

Research and Development (R\&D) conducted to bring a much-needed cross-cultural perspective to the issues surrounding disciplines and workplace. The R\&D method used to develop specific product and examine effectiveness of the product in the area of the development (Desai and Potter, 2006; Sugiyono, 2011). Therefore, $R \& D$ research was the type of this research because it used to develop a product. The researcher conducts this research to develop a new product through handout of English for Nursing. The ADDIE served for Analyzing, Designing, Developing, Implementation, and Evaluation. There were two kinds of data were taken for this research. The quantitative data were taken through results of the questionnaires and test. The qualitative data were gained from the result of interview. To collect the data, there are three kinds of instruments that used in this research to collect data of the research, namely: questionnaires, interview guidance, and validation checklist forms. The questionnaires were used two times by the researcher. Firstly, the questionnaires were used to gain data of students needs toward English teaching/learning and it placed in the analysis phase. Secondly, the questionnaires were used to get the data/information about the users perception from the students (the end-user of the product) about the developed handout. The interview guidance was used in the two phases. First, the interview guidance was used in the analysis phase to gain information about lacks, wants, and necessities of English teaching/learning as well as to select topics/contents, task, and other aspects that should be available in the handout. The informants were English lecturer, nursing lecturer, chief of nursing study program, and expert of English Education in Padang Sidempuan. In the second, the interview guidance was used in the implementation phases. The information gathered from this phase was used to find out the practicality of the developed handout in the 


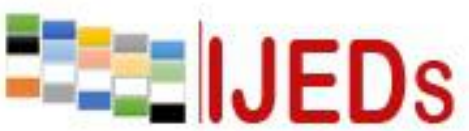

http://ijeds.ppj.unp.ac.id/index.php/IJEDS

development process from the English lecturer. In the last, forms of validation were used to validate the developed handout. The data gained from the instruments were analyzed qualitatively and quantitatively. The data from the result of interview was analyzed qualitatively. Then the data from the results of questionnaires and forms of validation were analyzed quantitatively. The techniques of analyzing the data were: a) need analysis; b) the validity of the developed handout; c) the practicality of the developed handout; and d) the effectiveness of the developed handout. For this case, the data of the needs analysis were gained from the questionnaires and the interview. The data were analyzed based on the frequency and percentage of the respondents. In another way, the result of interview was transcribed and it was classified based on the related indicators. Then the results of the questionnaires and the interview were triangulated to find out the target and learning needs. Then the validity of the developed handout was taken from the experts' judgments. Moreover, the data of practicality of the handout were taken through the questionnaires and the interview. The data gained from the questionnaires were analyzed based on the frequency of the respondents. In the last, effectiveness of the handout that developed was identified by using the data, namely the students' scores in pre-test and post-test through the experimental way (one class design).

\section{RESULTS AND DISCUSSION}

The results of this research was gained from the development process of developing English learning materials based on task-based learning for nursing study program at STIKES Aufa Royhan Padang Sidempuan. Therefore, the result was related to the process of the development. Analyze phase was conducted to know the students' needs in the learning of English. The target situation (the importance of learning English; students' progress in learning English; the expected skills and language points in learning English; the expected themes/topics) and learning needs (the reasons to learn English for Nursing; the available tasks/approaches/methods; need of designing and developing language teaching/learning materials based on task based learning) were taken as the dimensions in the analyze phase.

Based on the previous table, there were 19.1\% students showed that English very important, $27.5 \%$ students showed that the English was important, $22.5 \%$ students showed that the English was adequate important, 16.7\% students showed that the English was less important, and 14.2\% students showed that the English not important. 


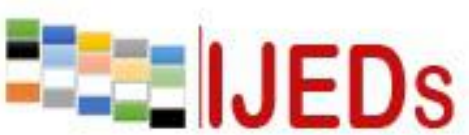

http://ijeds.ppj.unp.ac.id/index.php/IJEDS
International Journal of Educational Dynamics

Vol. 1 No. 1 (pp. 41-54) December 2018

p_ISSN 2655-4852

e ISSN 2655-5093

Therefore, the majority of the students of nursing study program at STIKES Aufa Royhan Padang Sidempuan showed that the English was important. It meant the students realized that English was important. Moreover the students pointed out that they needed English for Nursing to train skills of English and master language points that related to the nursing.

In the interview, English lecturer of nursing study program at STIKES Aufa Royhan Padang Sidempuan said the students need to learn English because majority of the manual instructions of nursing were faced in the English. Thus, the students needed to train the skills of English (reading, writing, listening, and speaking) and master the language points (grammar and vocabulary) that related to the nursing. Thus, English was important to the students. Then lecturer and chief of nursing study program at STIKES Aufa Royhan Padang Sidempuan explained that English was important. Then they said that the aim of English based on nursing was needed to determine until the students were able to train and master the appropriate skills and language points that related to the nursing. In addition, the expert of English Education in Padang Sidempuan clarified that the students of nursing program study needed to have English as the lesson in order the students were able to used English in supporting their study and future job about nursing.

The data of the previous table published that the students' progress in learning English were: $9.3 \%$ very good, $14,7 \%$ good, $24, \%$ adequate, $29.0 \%$ less, and $23.0 \%$ not good. It indicated that the almost of the students lack in learning English until they got problem in reading, writing, listening, and speaking. Moreover, the students were difficult to apply the language points that appropriate in learning English. The interview to the stakeholders (English lecturer, nursing lecturer, chief of nursing study program, and lecturer of English Education) was conducted to gain further information about the students' progress in learning English. In the results, they explained that the students were difficult to apply English in their study about nursing. The lacks of the students were listening, speaking, writing, and reading beside the related language points (grammar and vocabulary).

The previous data converted that the expectation of nursing program students at STIKES Aufa Royhan Padang Sidempuan were: 23.8\% strongly agree, 32.4\% agree, 


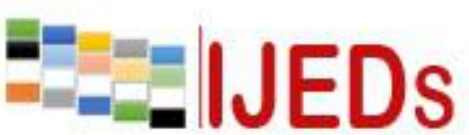

http://ijeds.ppj.unp.ac.id/index.php/IJEDS
International Journal of Educational Dynamics

Vol. 1 No. 1 (pp. 41-54) December 2018

p_ISSN 2655-4852

e_ISSN 2655-5093

$26.4 \%$ adequate, $11.2 \%$ less, and $6.2 \%$ strongly disagree to get language skills, language points and train both of them in the learning English. For this case, the data indicated that the students wanted to train language skills (listening, speaking, reading, and writing) and master language points of the English through task based learning. Moreover, the students wanted to have access in training their language points and language skills until they were able to place English in their studying about nursing or future job. Therefore, the students wanted to have more tasks to train their language skills and language points.

Based on the interview to the informants (lecturer of English, lecturer and chief of Nursing, and expert of English teaching/learning) they argued that the students of nursing study program at STIKES Aufa Royhan Padang Sidempuan should have access in training their language skills and language points until the students were able to use English in nursing. It should be clear from the syllabus/aim of the teaching/learning in the learning English.

The data of the previous table confirmed that almost the students expected to get many themes/topics in the learning English, such as: nursing profession, hospital, pain, symptoms, monitoring patients, death and dying. Furthermore, the result of interview from the informants (lecturer of English, lecturer and chief of nursing study program, and lecturer of English Education) clarified that the students were appropriate to get the themes/topics in the learning English, especially for the mid-semester. For this case, the respondents argued that the students needed to get the themes/topics in order the students were able to place the English in the nursing context. Finally, the themes/topics were taken to develop in the developed handout with the language skills and language points that related to them.

Based on the previous data, there were 25\% students confirmed that English for Nursing was important, $31.7 \%$ students agree that English for Nursing was important, 31.7\% students showed that English for Nursing was adequate important, 8.4\% students argued that English for Nursing was less important, and 3.4\% students clarified that English for Nursing was not important. Moreover, the students showed that the lesson of English should be focused into English for Nursing. Thus, the students were able to train the appropriate skills and language points that related to the nursing 


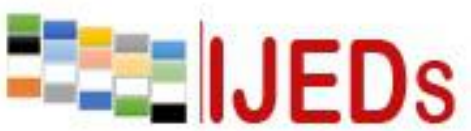

http://ijeds.ppj.unp.ac.id/index.php/IJEDS

context. In the last, the students clarified that the lesson of English needed to be narrowed into English for Nursing.

In the interview about the important of English for Nursing, the lecturer of English said the aim of English teaching/learning were not determine based on the students' needs. The syllabus of English was determined by the collage. Then the lecturer and chief of nursing study program confirmed that almost the syllabus in the nursing study program was determined without looking the students' needs. Meanwhile, the expert of English teaching/learning in Padang Sidempuan offered the syllabus of English for nursing should be taken by looking the students' needs.

Secondly, the others item were used to gather data about the materials/references used in the learning of the English. The items served to know the materials/references used in supporting the learning of English. The previous data clarified the students confirmed that the materials/references currently used were not good to catch English for Nursing. It meant that the students were difficult to train language skills that appropriate to place in the nursing context. Therefore, the majority of the students argued that their current learning of English was not support to the English for Nursing. Furthermore, the lecturer of English clarified that she conveys the lesson of English without looking the students' needs toward English for Nursing. It meant the lecturer used the general materials of English. Data showed that there were $17.8 \%$ students taught that the available of tasks/approaches/methods were very good, $21.1 \%$ students showed that available of tasks/approaches/methods were good, $28.9 \%$ students argued that available of tasks/approaches/methods were adequate good, $15.6 \%$ students pointed out that the available of tasks/approaches/methods were less good, and $16.7 \%$ students told that the available of tasks/approaches/methods were not good. It indicated the available of tasks/approaches/methods were not good to catch the English for Nursing.

Furthermore, the result of interview indicated that the available of tasks/approaches/methods currently used in teaching/learning of English were not appropriate. The students got less tasks/exercises or opportunity in training their skills that integrated in the nursing context. In the last, the informants offered that the available of tasks/approaches/methods needed to design and develop to get the specific 


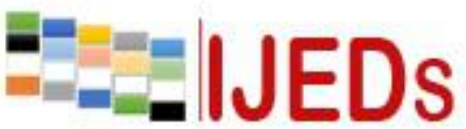

http://ijeds.ppj.unp.ac.id/index.php/IJEDS

purpose in the nursing context. Based on the data in the previous table, there were $20.0 \%$ of the students strongly agree that the materials in the learning of English needed to be designed and developed based on the task-based learning, $21.7 \%$ agree, $30.0 \%$ adequate agree, $20.0 \%$ less agree, and $8.4 \%$ strongly disagree. It indicated that majority of the students agree to get the materials/handout based on task-based learning.

In the interview to the informants, the researcher clarified that they were agree about the designing and developing the materials based on the task-based learning. The respondents argued that the development opened the students' access in learning English based on the specific purpose, namely English for Nursing. Finally, the designing and developing of teaching/learning materials based on the task-based learning was needed to be done.

This phase was taken to determine the design/blueprint of the developed products in the development process of this research. There were many points that needed to look as gap in determining the students' needs of learning English and they were showed in the table below.

Table 1. The Gap Points of Students' Needs in the Learning English

\begin{tabular}{c|l}
\hline Nu. & \multicolumn{1}{c}{ GAP POINTS } \\
\hline 1. & $\begin{array}{l}\text { The students realized that English was important, hence, they needed to train language skills } \\
\text { and master the language points of the English. }\end{array}$ \\
\hline 2. & $\begin{array}{l}\text { The students were still lacks in mastering English and training the skills of the English. } \\
\text { Therefore, the students realized that they should train their skills on reading, writing, listening } \\
\text { and speaking. }\end{array}$ \\
\hline 3. & $\begin{array}{l}\text { The students wanted to get themes/topics in the teaching/learning of English which facing the } \\
\text { nursing context, such as: nursing profession, hospital, pain, symptoms, monitoring patients, } \\
\text { death and dying. }\end{array}$ \\
\hline 4. & $\begin{array}{l}\text { The students realized that the teaching/learning of English should be placed based on the } \\
\text { students' needs until they got opportunity to use English based on the specific purpose, such as } \\
\text { English for Nursing. }\end{array}$ \\
\hline 5. & $\begin{array}{l}\text { The students wanted the teaching/learning of English were conveyed in the students' centered } \\
\text { (task-based learning) in order they got more opportunity/tasks in training their skills and } \\
\text { enlarging language points (grammar and vocabulary of nursing) mastery. }\end{array}$ \\
\hline 6. & $\begin{array}{l}\text { The students realized that task-based learning allowed being active in the teaching and learning } \\
\text { process. By having the task-based learning, the students were able to train language skills based } \\
\text { on the specific purpose in the nursing context. }\end{array}$ \\
\hline 7. & $\begin{array}{l}\text { The current syllabus and materials were not appropriate with the students' need in the nursing } \\
\text { context. Thus, it needed to design and develop the syllabus and materials based on the specific } \\
\text { purpose in order the students got the English for Nursing. }\end{array}$ \\
\hline
\end{tabular}




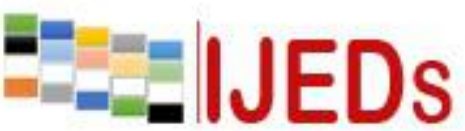

http://ijeds.ppj.unp.ac.id/index.php/IJEDS

Based on the previous explanation, it was clear that the students of nursing study program at STIKES Aufa Royhan Padang Sidempuan needed the developed handout of English for Nursing based on the task-based learning. The result of needs analysis was taken as the consideration in developing handout of English for Nursing based on task-based learning, such as the elaboration in the table below.

Table 2. The Points of Developed Handout of English for Nursing

\begin{tabular}{c|l|c|c|c|c}
\hline Nu. & \multicolumn{1}{|c|}{ Themes/Topics } & Text & $\begin{array}{c}\text { Language } \\
\text { Skills }\end{array}$ & $\begin{array}{c}\text { Language } \\
\text { Points }\end{array}$ & Tasks \\
\hline 1. & Nursing Profession & $\sqrt{ }$ & $\sqrt{ }$ & $\sqrt{ }$ & $\sqrt{ }$ \\
\hline 2. & Hospital & $\sqrt{ }$ & $\sqrt{ }$ & $\sqrt{ }$ & $\sqrt{ }$ \\
\hline 3. & Symptoms & $\sqrt{ }$ & $\sqrt{ }$ & $\sqrt{ }$ & $\sqrt{ }$ \\
\hline 4. & Pain & $\sqrt{ }$ & $\sqrt{ }$ & $\sqrt{ }$ & $\sqrt{ }$ \\
\hline 5. & Monitoring Patients & $\sqrt{ }$ & $\sqrt{ }$ & $\sqrt{ }$ & $\sqrt{ }$ \\
\hline 6. & Death and Dying & $\sqrt{ }$ & $\sqrt{ }$ & $\sqrt{ }$ & $\sqrt{ }$ \\
\hline
\end{tabular}

Based on the previous table, the data showed that there were six themes/topics that needed by students to learn in the teaching/learning process, such as: nursing profession, hospital, symptoms, pain, monitoring patients, and death \& dying. Moreover, the students needed to have tasks to train their language skills (reading and writing) and language points (vocabulary, grammatical enhancement and glossary) through the developed themes/topics. In other side, the developed handout was filled with appropriate text to enrich and enlarge information or terminologies of the students about nursing. Furthermore, the developed handout was validated to the experts (experts' judgments) to find out the validation of the product by offering the questionnaire. The experts come from (A) Education of Language, (B) Technology of Education, (C) Practitioner of English, and (D) Practitioner of Nursing. For this case, there were four dimensions used, namely: language/linguistics, process/methodology, content/product, and the layout. The result showed in the table below. 
Table 3. The Result of Experts' Judgments for Validity

\begin{tabular}{c|l|c|c|c|c}
\hline \multirow{2}{*}{ Nu. } & \multicolumn{2}{|c|}{ Dimensions/Indicators } & \multicolumn{4}{|c}{ Experts' Judgments } \\
\cline { 3 - 6 } & & A & B & C & D \\
\hline 1. & Linguistics & 12 & 13 & 12 & 12 \\
\hline 2. & Methodology & 17 & 18 & 17 & 14 \\
\hline 3. & Content & 19 & 23 & 20 & 21 \\
\hline 4. & Layout & 10 & 10 & 10 & 10 \\
\hline SUM & $\mathbf{5 8}$ & $\mathbf{6 4}$ & $\mathbf{5 9}$ & $\mathbf{5 7}$ \\
\hline AVERAGE & $\mathbf{2 . 9}$ & $\mathbf{3 . 2}$ & $\mathbf{2 . 9}$ & $\mathbf{2 . 8}$ \\
\hline TOTAL AVERAGE & \multicolumn{5}{|c}{ GOOD } \\
\hline CATEGORY & \multicolumn{5}{|c}{} \\
\hline
\end{tabular}

Based on the data, it was clear that the developed handout was good. It meant that the developed handout was valid even there were many points that needed to revise in the developed handout. There were many points that needed to consider after having validation toward the developed handout in the development process. In the previous information, the developed handout was completed after revision in which it faced in the clear and systematic order until the students were able to determine their target through the developed handout. Therefore, the developed handout was valid to use by the students in the teaching/learning process. Finally, the developed handout was ready to apply in the implementation phase.

Implementation phase was conducted after developing the handout of English for Nursing into limited try-out. It was applied to find out the practicality of the developed handout. Therefore, the further explanation showed the practicality of the developed handout.

Table. 4. The Result of Students' Responses about the Practicality

\begin{tabular}{c|l|c|c|c|c|c}
\hline \multirow{2}{*}{ Nu } & \multicolumn{1}{|c|}{ Dimension/Indicator } & \multicolumn{5}{|c}{ Students' Response (\%) } \\
\cline { 4 - 7 } & & $\begin{array}{c}\text { Very } \\
\text { Good }\end{array}$ & Good & Adequate & Less & Not Good \\
\hline I. & Dimension of Language Area & & & & & \\
\hline 1. & $\begin{array}{l}\text { Audience of English in the } \\
\text { developed handout }\end{array}$ & 25.0 & 41.7 & 25.0 & 5.0 & 3.4 \\
\hline 2. & $\begin{array}{l}\text { The appropriate of the aim of } \\
\text { English teaching/learning process in } \\
\text { the developed handout }\end{array}$ & 30.0 & 36.6 & 30.0 & 2.2 & 1.1 \\
\hline II. & Dimension of Contents & & & & & \\
\hline 3. & $\begin{array}{l}\text { Language points/linguistics } \\
\text { description of the developed } \\
\text { handout }\end{array}$ & 23.8 & 38.8 & 31.3 & 6.3 & 0.0 \\
\hline
\end{tabular}


http://ijeds.ppj.unp.ac.id/index.php/IJEDS

\begin{tabular}{c|l|c|c|c|c|c}
\hline 4. & $\begin{array}{l}\text { Language skills of the developed } \\
\text { handout }\end{array}$ & 11.7 & 26.7 & 43.4 & 11.7 & 6.7 \\
\hline 5. & $\begin{array}{l}\text { Themes/topics, and texts of the } \\
\text { developed handout }\end{array}$ & 25.0 & 30.0 & 40.9 & 4.2 & 0.0 \\
\hline 6. & $\begin{array}{l}\text { Organization of contents in the } \\
\text { developed handout }\end{array}$ & 19.7 & 27.6 & 40.6 & 11.5 & 0.6 \\
\hline III. & Dimension of Methodology & & & & & \\
\hline 7. & $\begin{array}{l}\text { The existed of method/approach } \\
\text { through the developed handout }\end{array}$ & 18.5 & 27.8 & 35.9 & 14.1 & 3.7 \\
\hline 8. & $\begin{array}{l}\text { The existed of Task-based Learning } \\
\text { through the developed handout }\end{array}$ & 26.7 & 33.3 & 33.3 & 6.7 & 0.0 \\
\hline 9. & $\begin{array}{l}\text { The extent of tasks/texts used in the } \\
\text { developed handout }\end{array}$ & 20.8 & 29.6 & 37.9 & 7.5 & 4.2 \\
\hline 10. & $\begin{array}{l}\text { The relevance of instructional/units } \\
\text { in the developed handout }\end{array}$ & 20.0 & 30.0 & 28.3 & 18.4 & 3.4 \\
\hline
\end{tabular}

In the language area, the data showed $25.0 \%$ students were agree that audience of English in the developed handout was very good, $41.7 \%$ good, $25.0 \%$ adequate good, $5.0 \%$ less good, and $3.4 \%$ not good. Therefore, the students pointed out that the developed handout was practice for them as the audience of the English for Nursing. In the aim of English teaching/learning process, the students argued that the developed handout was appropriate for them. There were $30.0 \%$ students argued that the aim was very good, $36.6 \%$ students showed that the aim was good, $30.0 \%$ of the students explained that the aim of English teaching/learning process adequate good with the nursing context, 2.2\% students clarified that the aim less good, and $1.1 \%$ students believed that the aim was not good with them in the English teaching/learning process. For this case, it was interpreted that the aim of the teaching/learning process in the developed handout gave the students opportunity to catch English for Nursing.

The evaluation conducted to know whether the developed handout effectively in the teaching/learning process. Try-out through experimental way (one-class design) was taken to determine the effectiveness in the developed handout. In other words, the experimental way (one-class) design was used to know the effectiveness of the developed handout. For this case, the researcher gave test (pre-test) to the students (30 students) before having the limited try-out and the test (post-test) was distributed to the students after having the try-out to find out the effectiveness of the developed handout. Then difference between the results of pre-test and post-test was taken as the consideration to determine the effectiveness of the developed handout. 


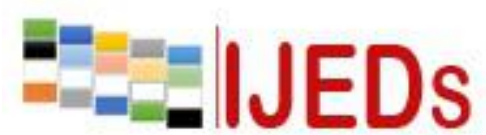

http://ijeds.ppj.unp.ac.id/index.php/IJEDS

\section{CONCLUSION}

Nursing study program students at STIKES Aufa Royhan Padangsidimpun needed to learn English based on nursing context as well as to train language skills and the other aspects of English in catering the needs. The needs of the students were taken to develop the handout of English for nursing based on task-based learning. Then the ADDIE model was taken as the procedures of the research in producing the developed handout of English for nursing. In the validation of the developed handout, the experts' judgments showed that the developed handout was valid with revision. Furthermore, the users' perceptions toward developed handout were effective and practice

\section{REFERENCES}

Bojović, M. 2006. Teaching Foreign Language for Specific Purposes: Teacher Development. Retrieved at $3^{\text {rd }}$ August 2015.

Desai, V and P. Robert. 2006. Doing Development Research. London: SAGE Publications.

Ellis, R. 2014. Taking the Critics to Tasks: The Case for Task-based Teaching. Proceedings of CLaSIC 2014. Retrieved 21 th November 2017.

Estaire, S and Z. Javier. 2003. Planning Classwork A Task-Based Approach. Hong Kong: MacMillan Publishers Ltd.

Evans, D. T and Jhon, St. Jo Maggie. 2008. Developments in English for Specific Purposes; A Multi-Disciplinary Approach. New York: Cambridge University Press.

Finch. 2014. Carring in English: ESP for Nurses. International Journal of English Language Teaching. Vol. 1, No. 1; 2014. Retrieved 30 ${ }^{\text {th }}$ March 2016.

Field, Kit. (Editors). 2011. Issues in Modern Foregin Language Teaching. New York: Routledge.

Hutchinson, T and W. Alan. 2008. English for Specific Purposes; A Learning-Centered Approach. New York: Cambridge University Press.

Hyland, K. 2006. English for Academic Purposes, An Advance Resource Book. New York: Routledge.

Mikits, J. 2009. The Use of Classroom Handout. Paper of Center for Teaching Excellence. Retrieved $18^{\text {th }}$ November 2017.

Nunan. 2004. Task-Based Language Teaching. New York: Cambridge University Press.

Sugiyono. 2011. Metode Penelitian Pendidikan, Pendekatan Kuantitatif, Kualitatif, dan R \& D. Bandung: Alfabeta.

Syah, M. 2010. Psikologi Pendidikan Pendekatan Baru. Bandung: Remaja Rosdakarya. Windari, D. 2014. The Development of Learning Material of Nursery English through Task-Based Activties. Jurnal Linguistik Terapan Pascasarjana Unimed. 11 (1) (2014):70-80. Retrieved 11 $1{ }^{\text {th }}$ November 2016. 